\title{
Interpretation of anatomical characters in phylogenetic analysis of Pinnipedia, with emphasis on Otariidae (Mammalia, Carnivora)
}

\author{
Daniela Sanfelice ${ }^{1 *}$ \\ César J. Drehmer ${ }^{2}$ \\ ${ }^{1}$ Instituto Federal de Educação, Ciência e Tecnologia do Rio Grande do Sul \\ Avenida Machado de Assis, 1456, Osório, CEP 95520-000 - RS, Brasil \\ ${ }^{2}$ Departamento de Zoologia e Genética, Universidade Federal de Pelotas \\ Caixa Postal 354, CEP 96010-900, Pelotas - RS, Brasil \\ * Correspondence author \\ daniela.sanfelice@gmail.com
}

Submetido em 12/09/2012

Aceito para publicação em 14/03/2013

\section{Resumo}

Interpretação dos caracteres anatômicos em análises filogenéticas dos Pinnipedia, com ênfase em Otariidae (Mammalia, Carnivora). A partir da década de oitenta, a hipótese de que os pinipédios teriam uma origem comum ganhou espaço nos debates centrados na sistemática desse grupo. Todavia, o conhecimento restrito acerca da anatomia de muitas espécies e as frequentes variações nos estados de diversos caracteres dificultam a elucidação das relações filogenéticas dos pinipédios. Objetivou-se revisar os caracteres anatômicos do sincrânio e da dentição empregados nas análises filogenéticas, tendo por base os otarídeos Otaria byronia $(\mathrm{n}=25)$ e Arctocephalus australis $(\mathrm{n}=48)$. Algumas interpretações dos caracteres utilizados na literatura revelaramse questionáveis. Destacam-se: (1) forma e posição da tuberosidade pré-maxilar; (2) orientação da série de alvéolos pós-caninos maxilares; (3) fossa naso-labialis; (4) forma da sutura do jugal com o processo zigomático do temporal; (5) relevo do timpânico; (6) relação da altura do processo condilar com a série alveolar dos póscaninos inferiores; (7) individualização do canal do aqueduto coclear e janela redonda; (8) separação de canais no meato acústico interno para os nervos cranianos VII e VIII; (9) presença de cíngulo lingual no terceiro incisivo superior; (10) desenvolvimento do metacônido do quinto pós-canino superior e (11) número de raízes do segundo ao quarto pós-caninos superiores e do quinto pós-canino inferior. Estas observações denotam a relevância e a necessidade de descrições anatômicas detalhadas dos pinipédios para o entendimento de sua evolução.

Palavras-chave: Crânio; Dentes; Filogenia; Pinnipedia; Sistemática

\section{Abstract}

The hypothesis that pinnipeds have a common origin gained support during the 1980s in discussions focused on the systematics of the group. However, the limited knowledge of the anatomy of several species and the frequent variation in several character states make it difficult to clarify the phylogenetic relationships of pinnipeds. Our purpose was to review the anatomical characters of the syncranium and dentition used in phylogenetic analyses by studying the otariids Otaria byronia $(\mathrm{n}=25)$ and Arctocephalus australis $(\mathrm{n}=48)$. Some interpretations of characters presented in the literature were found to be questionable, notably: (1) shape and 
position of the premaxillary tuberosity; (2) orientation of the maxillary postcanine alveoli; (3) naso-labialis fossa; (4) shape of the jugal contact with the zygomatic process of temporal; (5) relief and length of the tympanic bone; (6) relationship between the height of the condylar process in relation to the lower postcanine teeth alveoli; (7) individualization of the canal of the cochlear aqueduct and round window; (8) separation of the openings for the cranial nerves VII and VIII in the internal auditory meatus; (9) lingual cingulum on the third upper incisor; (10) development of the metaconid of the fifth upper postcanine tooth, and (11) number of roots in the second to fourth upper postcanine teeth and fifth lower postcanine tooth. These observations indicate the relevance and the need for detailed anatomical descriptions of pinnipeds for understanding their phylogenetic relationships and, consequently, their evolutionary relationships.

Key words: Phylogeny; Pinnipedia; Skull; Systematic; Teeth

\section{Introduction}

Since the $19^{\text {th }}$ century, there has been controversy concerning the origin, evolution and phylogenetic relationships of pinnipeds. Until the last decades, a diphyletic origin for the Pinnipedia was the prevailing hypothesis (Otariidae and Odobenidae would share a common ancestor with the Ursidae; whereas Phocidae would share a common ancestor with the Mustelidae (MITCHELL; TEDFORD, 1973; TEDFORD, 1976).

This scenario changed during the second half of the 1980s (WYSS, 1987; 1988a; 1988b; 1989), especially due to the reinterpretation of diagnostic characters, studies of the postcranial skeleton (WYSS, 1988b; WYSS, 1989) and discovery of new fossil species (BERTA, 1991; 1994; DEMÉRÉ; BERTA, 2001; 2002; 2005; DAVIS et al., 2004; UHEN, 2007), which supported the idea of an arctoid common ancestor for the Pinnipedimorpha. This hypothesis is also supported by studies based on molecular data (FLYNN et al., 2005; HIGDON et al., 2007; DASMAHPATRA et al., 2009). DREHMER (2000) presented a historical review of the hypotheses favoring a single origin for the Pinnipedia, corroborating previous interpretations (e.g. WYSS, 1989).

In effect, several systematic arrangements have been proposed (TEDFORD, 1976, for the biphyletic hypothesis; and BERTA, 1994; DEMÉRÉ et al., 2003, for the monophyletic one), but to date, there is no consensus on the phylogenetic relationships between Pinnipedia and of these concerning the other carnivores. Árnason et al. (2006), using molecular characters, showed Pinnipedia as a monophyletic clade, considering the Otariidae+Odobenidae as a basal divergence inside the group, followed by the Phocidae.
Recently, Berta and Churchill (2012) stated that Pinnipeds are a charismatic but hard-to-study group, and that the taxonomy is unclear, particularly the relevance of an accurate taxonomic framework for biogeography, ecology and conservation.

In addition, there is limited knowledge about the anatomy of several species (examples of skull descriptions in HOWELL, 1929; SIVERTSEN, 1954; REPENNING et al., 1971; KING, 1983; ANDREESCU; MURARIU, 1985; KASTELEIN; GERRITS, 1990; DREHMER; FERIGOLO, 1996a; 1997; MIZUNO; OHTAISHI, 2002; SANFELICE; FERIGOLO, 2008), and the frequent variability in the cranial (NOJIMA, 1990), postcranial (ROBINETTE; STAINS, 1970; ENGLISH, 1977) and dental (DREHMER; FERIGOLO, 1996b; DREHMER et al., 2004; CRUWYS; FRIDAY, 2006; LOCH et al., 2010) character states, which makes it even more difficult to clarify the relationships of this group.

The purpose of the present study was to review the anatomical characters of the syncranium and dentition used in phylogenetic systematics of Pinnipedia, through the study of the representative Otariidae species Arctocephalus australis (ZIMMERMAN, 1783) and Otaria byronia (DE BLAINVILLE, 1820). This is important considering that phylogenetic relationships between otarids are still controversial (BERTA; CHURCHILL, 2012).

Concerning the taxon Otaria byronia, Wozencraft (2005), following Rodriguez and Bastida (1993), suggested that the specific name "flavescens" had priority over "byronia," but we support the use of the specific name "byronia," as recommended by the International 
Commission on Zoological Nomenclature (GARDNER; ROBBINS, 1999; ICZN, 2000). In addition, although both type specimens are lost, an illustration of the skull of the type specimen of "byronia" in palatal view still exists, which provides unequivocal evidence for the identification of this species (BERTA; CHURCHILL, 2012).

\section{Material and Methods}

Comparative analysis was based on morphological characters following Berta and Deméré (1986), Berta (1991) and Berta and Wyss (1994).

Material represented adult or subadult individuals, with a minimum suture age of 17 (see SIVERTSEN, 1954) and total skull length greater than 300 and $200 \mathrm{~mm}$ for males, and 240 and $195 \mathrm{~mm}$ for females of Otaria byronia and Arctocephalus australis, respectively (see DREHMER; FERIGOLO, 1997; DREHMER et al., 2004).

Juvenile and subadult individuals were used for the analysis of some of the sutures. The dental study required the analysis of teeth from all age ranges, due to wearing during development, since tooth replacement occurs at an early age, more precisely at 4-5 months in the Otariidae (MIYAZAKI, 2002). Comparisons between the species were performed with specimens of the same gender. The skull and tympanic cavities were studied in specimens MCN 2459 (O. byronia) and MCN 2501 ( $A$. australis), after parasagittal sectioning and removal of the tympanic bones.

The term "postcanine" was kept instead of using "premolar" and "molar," as accepted for recent Otariidae species, due to the morphological similarity of postcanines (BARNES, 1989; DREHMER et al., 2004).

The terminology was adapted from Howell (1929), Klaauw (1931), Miller et al. (1964), Mitchell (1968), Mitchell and Tedford (1973), Tedford (1976), Barnes (1972; 1979; 1987; 1989; 1990; 1992), Repenning and Tedford (1977), Berta (1994), Berta and Wyss (1994) and Drehmer and Ribeiro (1998). Dental nomenclature followed Hershkowitz (1971) and Barnes (1989).

Whenever possible, the anatomical description followed the international nomenclature standards of the
International Committee on Veterinary Gross Anatomical Nomenclature (1994) and Mead and Fordyce (2009). The acronym GEMARS stands for "Grupo de Estudos de Mamíferos Aquaticos do Rio Grande do Sul," MCN for "Museu de Ciências Naturais (Fundação Zoobotânica do Rio Grande do Sul)," UNISINOS for "Universidade do Vale do Rio dos Sinos" and UFSC for "Universidade Federal de Santa Catarina." The abbreviation "I" refers to incisive teeth, while "PC" refers to postcanine teeth. A slash after the tooth number (e.g. I1/) indicates that the same belongs to the upper row, while a slash before the tooth number (e.g. I/1) indicates that it belongs to the lower row.

\section{Material examined}

Arctocephalus australis. BRASIL, Santa Catarina: Praia da Armação, Florianópolis, 10ิ, 19.VIII.1988, S. Althoff (UFSC 1063); Caeira da Bara do Sul, Florianópolis, 1 , , 12.VII.1994, M. Becker (UFSC 1133); Barra Velha, 1Ō, 19.08.1996, IBAMA (UFSC1228); Rio Grande do Sul: Litoral riograndense, 19, 04. IX.1990, V. Petry col. (UNISINOS 106); Litoral norte, entre Tramandaí e Mostardas, 10 , 08.X.1991, GEMARS (UFSC 1135); Litoral Norte, 3 §ิ, 03. IX. 1993, GEMARS (UFSC 1142, 1143, 1149); 5今, 16.X.1993, GEMARS (UFSC 1154, 1156, $1157,1158,1159) ; 1 \hat{\jmath}, 17.10 .1993$, GEMARS (UFSC 1160); 1ð, 06.XI.1993, GEMARS (UFSC 1163); 3 $ぇ$, 19.VIII.1996, GEMARS (UFSC 1166, 1169, 1170) Pinhal, 1Ō, 13.X.1997, V. Petry (UNISINOS 170); Santa Vitória do Palmar, 1ð̃, E. Martino col. (MCN 1021); 2ð, 1 IX.1990, J. Ferigolo col. (MCN 2461, 2522, 2523); 1ㅇ, 17.IX.1994, C. Drehmer col. (MCN 2614); 1 ㅇ, 18.IX.1995, C. Drehmer (MCN 2699) Cidreira, 2ð⿱ 22.VIII.1992, C. Drehmer (MCN 2495, 2508); 1q, 23.VIII.1992, C. Drehmer, (MCN 2509); Mostardas, 3 đ̂, 22.VIII.1992, C. Drehmer (MCN 2497, 2498, 2501); 1ठ⒚IX.1994, C. Drehmer (MCN 2645), 1q, 09.VI.1989, M. Strieder col. (UNISINOS 96), 01.XI.1990, M. Sander col. (UNISINOS 101); 1ð, 2 우, 13.X.1997, V. Petry col. (UNISINOS 157, 163, 164); Cassino, 1, V.1998, E. Borsato (MCN 2833); Rio Grande, 1ð̄, 16.IX.1994, C. Drehmer (MCN 2600); 1̧ิ, 1988, Clódio col. (MCN 2706); São José do Norte, 
2へ, 18.IX.1994, C. Drehmer (MCN 2627, 2630); $2 \hat{\jmath}$, 17.IX.1995, C. Drehmer (MCN 2688, 2689); Palmares do Sul, 2ð, 19.IX.1994, C. Drehmer (MCN 2649, 2650); Tavares, 1ठ, 16.IX.1995, C. Drehmer (MCN 2685); UNISINOS, 157, 163, 164, 170); URUGUAI, Depto. Rocha: Cabo Polônio, 1 ô, XI.1985, P.C. Simões-Lopes (UFSC 1057).

Otaria byronia. BRASIL, Rio Grande do Sul: Litoral norte, entre Tramandaí e Mostardas, 1 ઈ, 04. X. 1991, GEMARS (UFSC 1134), 1 §̋, 16. VIII. 1991, GEMARS (UFSC 1140); 1 ô, 36. IX. 1993 (UFSC 1152); 1 \%, 17.X.1993, GEMARS (UFSC 1162); 2 ๙, 19. XII. 1993, 2 ๙ GEMARS (UFSC 1168, 1171); 12.X.1997 Santa Vitória do Palmar, 3ð̂, IX. 1990, J. Ferigolo col. (MCN 2459, 2460, 2462), 1ð, 1 Ø, 17.IX.1994, C. Drehmer col. (MCN 2612, 2618), 20, 29, 18.IX.1995, C. Drehmer (MCN 2697, 2700, 2701, 2703); Mostardas, 1ð̂, 22.VIII.1992, C. Drehmer (MCN 2505); Rio Grande, 3ð , 1 q, 16.IX.1994, C. Drehmer (MCN 2601-2604); 1ð, 16.IX.1994, C. Drehmer (MCN 2624); 1ठ̂, VII.1997, E. Borsato col. (MCN 2807); São José de Norte, 1Ō, 18.IX.1994, C. Drehmer (MCN 2629); 1ð, 1 q, 17.IX.1995, C. Drehmer (MCN 2691, 2696); 1ð̂, VII.1998, E. Borsato (MCN 2832); 04.IX.1990, V. Petry (UNISINOS 107).

\section{Results}

The comparative study revealed that the interpretation of many characters presented in the literature is questionable.

Berta and Wyss (1994) postulated that the nasal process of the premaxilla is prominent, dorsal and anterior to the alveolar margin (state of character 1) in the genus Arctocephalus and in all sea lion species. However, we observed that in O. byronia, it is not prominent (state of character 0, following Berta and Wyss, 1994) (Figure 1).

Berta and Deméré (1986) suggested that the orientation of the postcanine alveolar series is clearly distinct between the "Arctocephalinae" and the sea lions. While in Arctocephalinae the series diverges posteriorly, it is more rectilinear in sea lions. However, the orientation of the postcanine alveolar series observed here differs from that described in Berta and Deméré (1986), since the postcanine series could show a medial curvature of variable degree (Figure 2) or even a discrete posterior divergence. Still, this character varies in skull ontogeny.

FIGURE 1: Nasal process of the premaxillary (arrow) not prominent in O. byronia (MCN 2629; scale, $2 \mathrm{~cm}$ ).

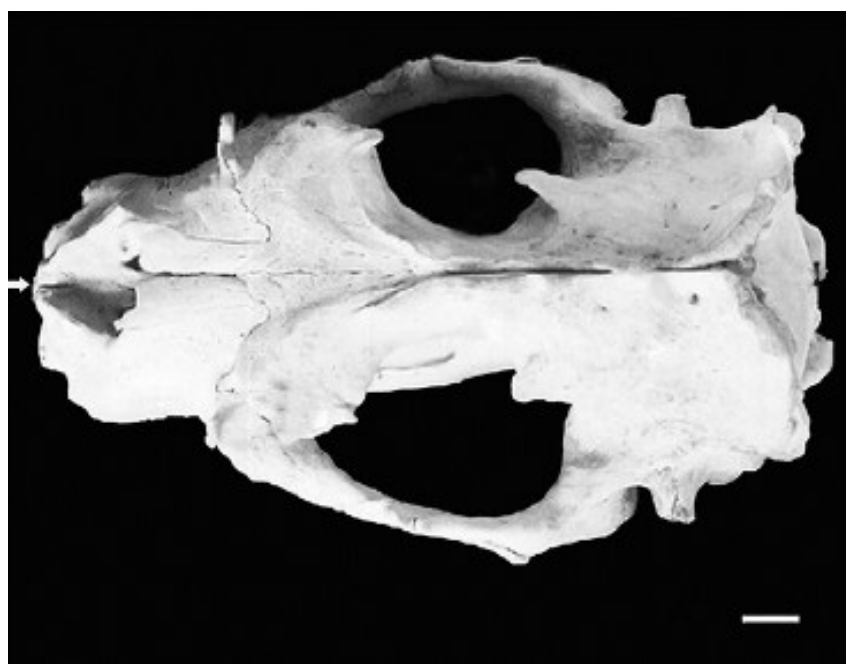

FIGURE 2: Orientation of the postcanine alveolar series showing medial concavity in Otaria byronia (MACN 4-3-12; scale, $2 \mathrm{~cm}$ ).

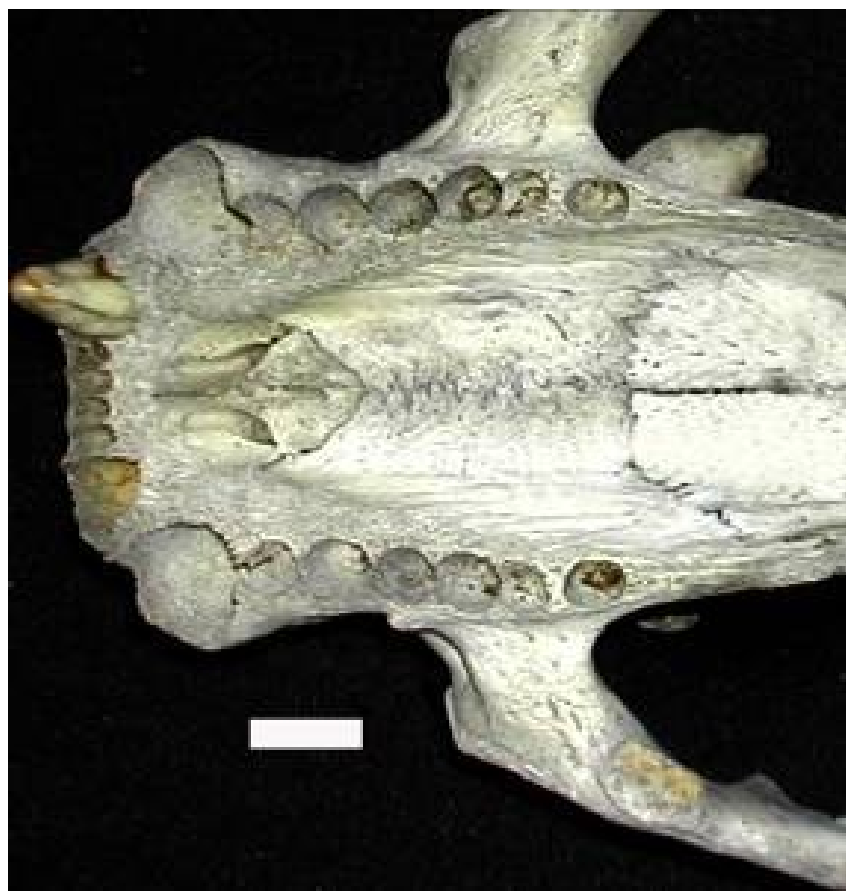


According to Berta and Wyss (1994), the absence of the nasolabialis fossa is characteristic in all Pinnipedia and it could have undergone a reversal in Pinnarctidion. However, this fossa was observed in some specimens (e.g. MCN 2629, MCN 1021) (Figure 3) of both species analyzed here.

Berta and Wyss (1994) described the contact between the jugal and zygomatic processes of the squamosal as "splintlike" in Arctocephalus spp. However, in Otaria byronia, this suture is "mortised" (Figure 4). The relief of the tympanics was also used by Berta and Deméré (1986) (character 40) in otariid phylogeny. These authors affirm that a prolonged ventral-posterior projection in the wall of the tympanic bulla is a synapomorphy of "Otariinae." However, such projections were also present in the A. australis specimens examined here (Figure 5).

A condylar process on the dentary above the level of postcanines was considered by Berta and Wyss (1994) as a synapomorphy of the fossil pinnipeds Desmatophoca, Piscophoca and Acrophoca (character 53). However, the specimens of $O$. byronia studied (Figure 6) showed the same characteristic (see specimens of Desmatophoca figured in Barnes (1987)).

According to Berta (1991), the canal of the cochlear aqueduct (character 24) is joined to the round window in Otariidae, but in the $O$. byronia specimens examined here these openings are clearly separate (Figure 7).

Berta and Wyss (1994: 48), when considering the condition of the internal auditory meatus (character 26), attributed to Arctocephalus and to the sea lion species the same character state (0): [...] "internal auditory meatus present and canals will be to vestibulocochlear and facial nerves closely adjacent"). However, A. australis actually possesses state (1): [...] "internal auditory meatus present and canals will be to vestibulocochlear and facial nerves incipiently separated "(BERTA; WYSS, 1994: 48) (Figure 8).

These authors also affirmed that the lingual cingulum in the $\mathrm{I} 3 /$ is absent in the modern otariids (character 59), contradicting the results of Drehmer and Ferigolo (1996a) and differing from that observed in the material of $A$. australis examined here (Figure 9), despite its occasional reduction (but not absence).

FIGURE 3: Nasolabialis fossa in Otaria byronia (MCN 2697; scale, $5 \mathrm{~cm}$ ).

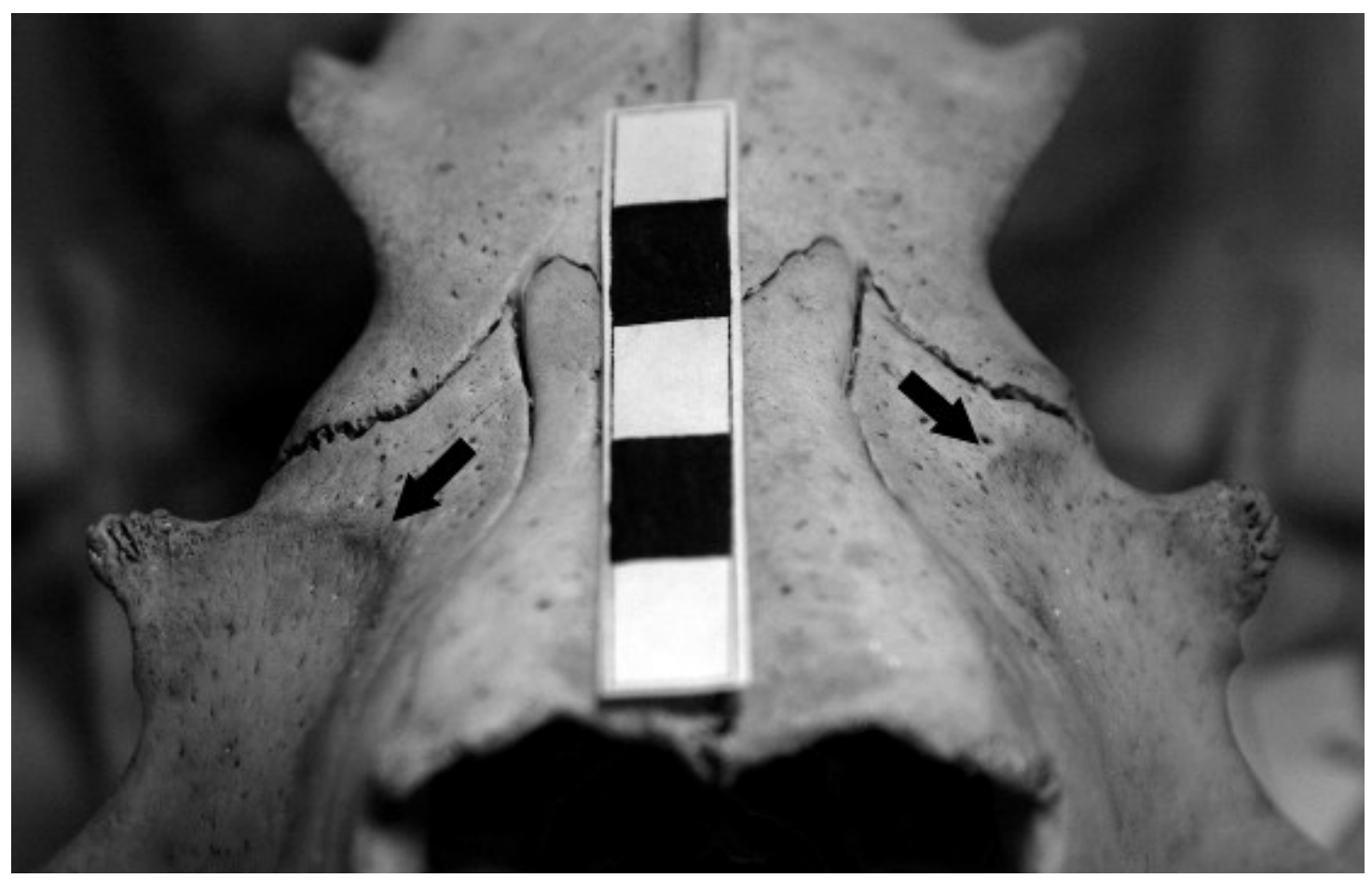


FIGURE 4: Articulation of the squamosal portion of the temporal of the "mortised" type (arrow) in Otaria byronia (MCN 2629).

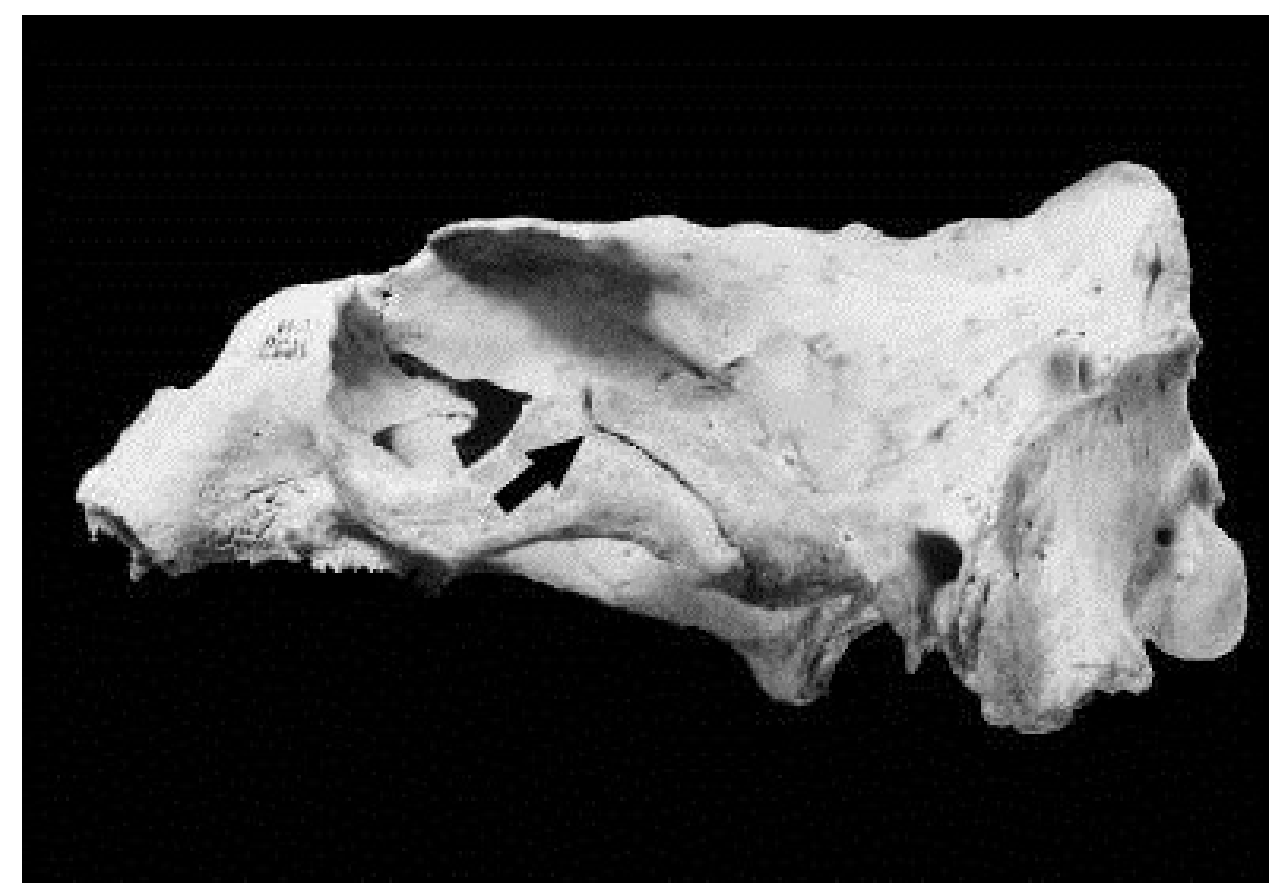

FIGURE 5: Presence of a prolonged posterior-ventral projection in the wall of the tympanic bulla in Arctocephalus australis (MCN 1021; scale, $5 \mathrm{~cm})$.

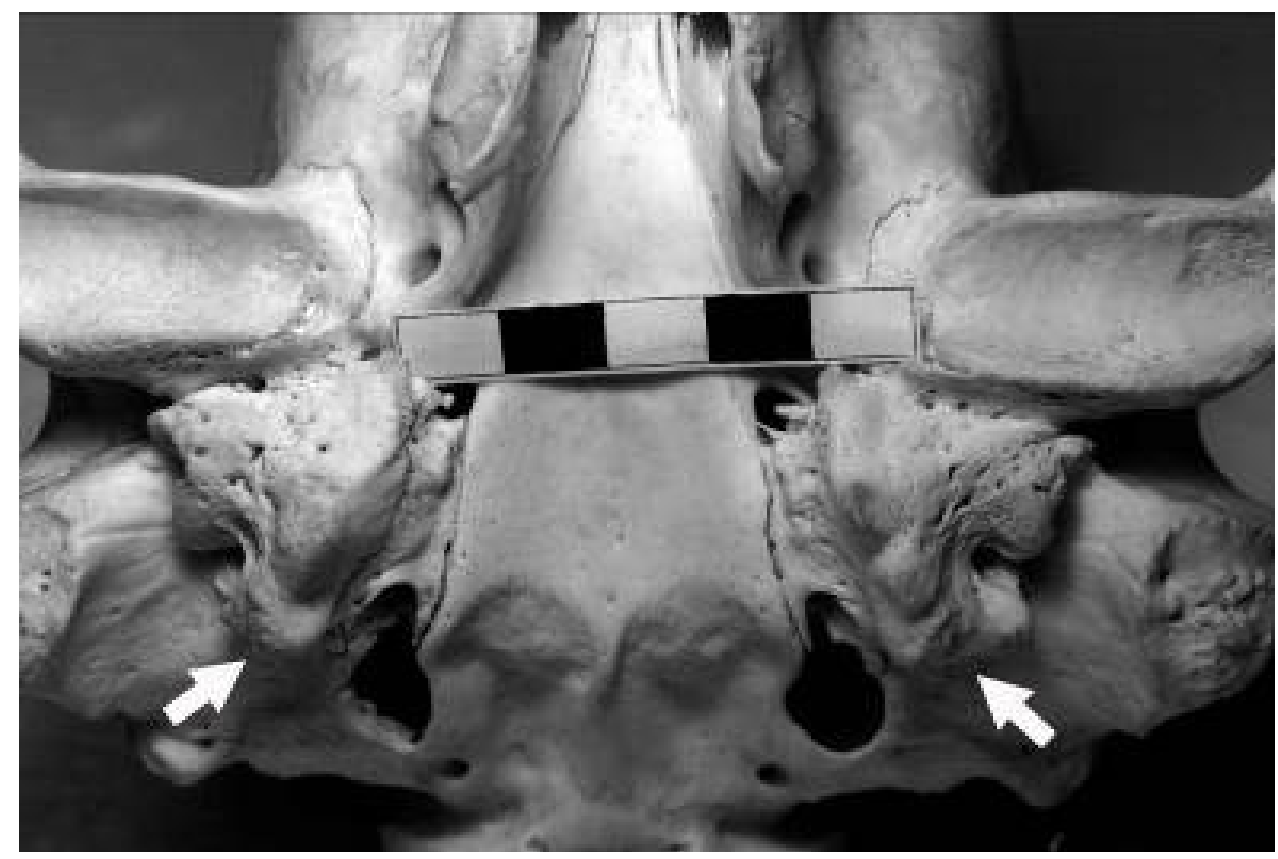


FIGURE 6: Condylar process above the level of the postcanine alveolar series in Otaria byronia (MCN 2629; scale, $5 \mathrm{~cm}$ ).

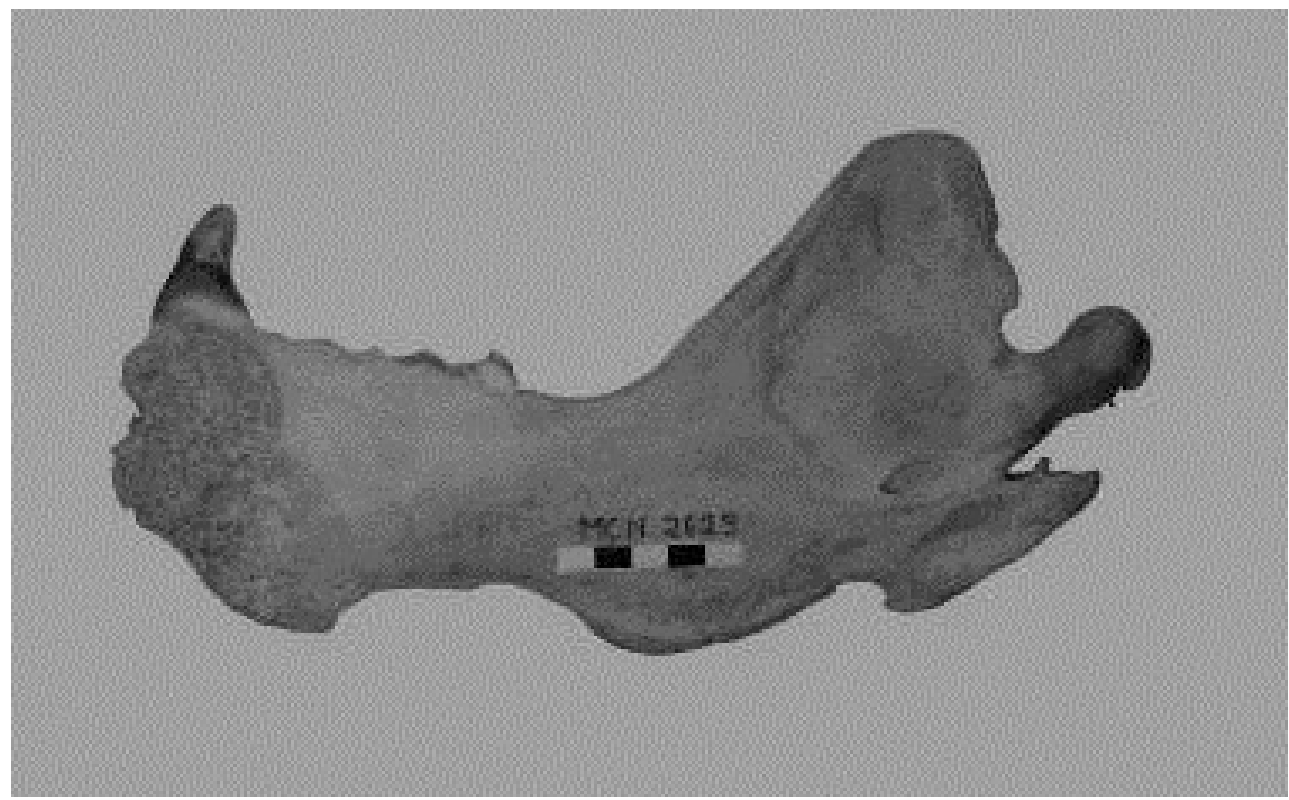

FIGURE 7: Canal of the cochlear aqueduct (white arrow) separate from the round window (black arrow) in Otaria byronia (MCN 2459; scale, $5 \mathrm{~cm}$ ).

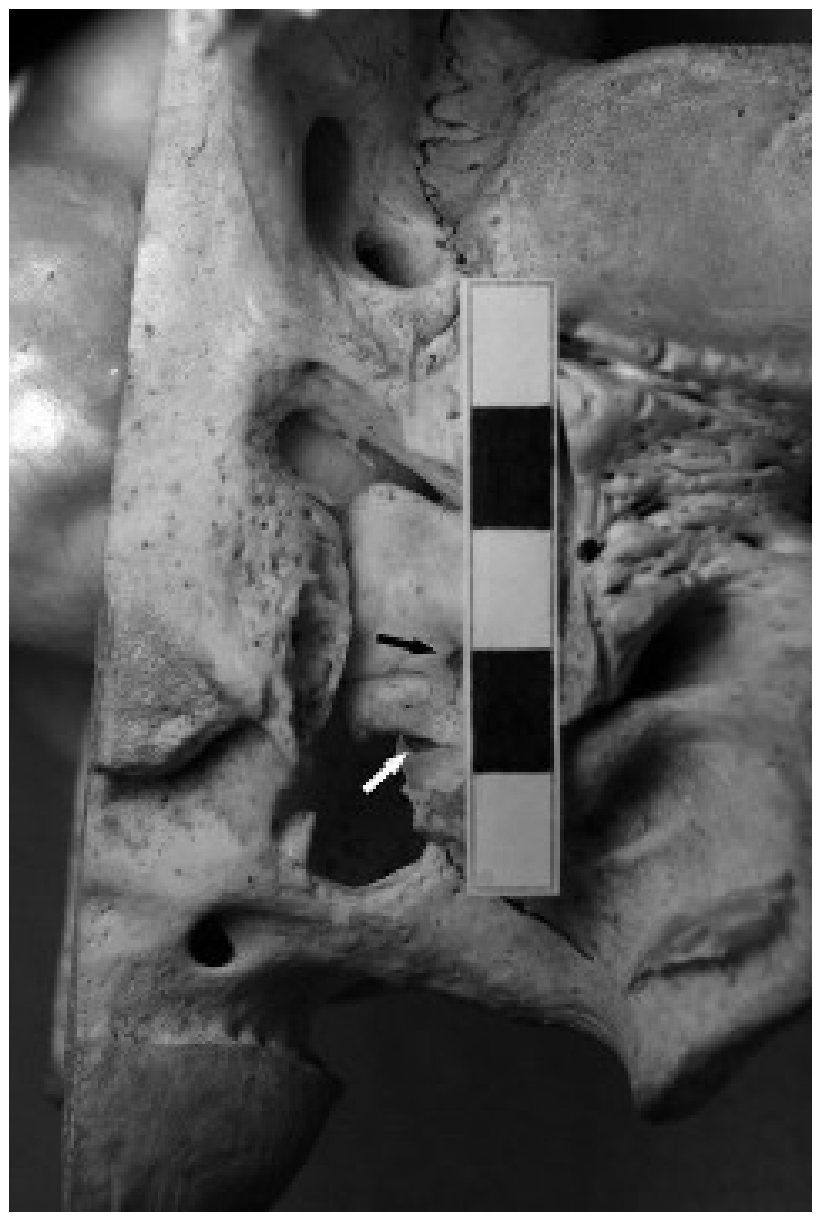


FIGURE 8: Internal auditory meatus showing incipient separation for the canals for the facial and vestibulocochlear nerves in Arctocephalus australis (MCN 2501; scale, $5 \mathrm{~cm}$ ).

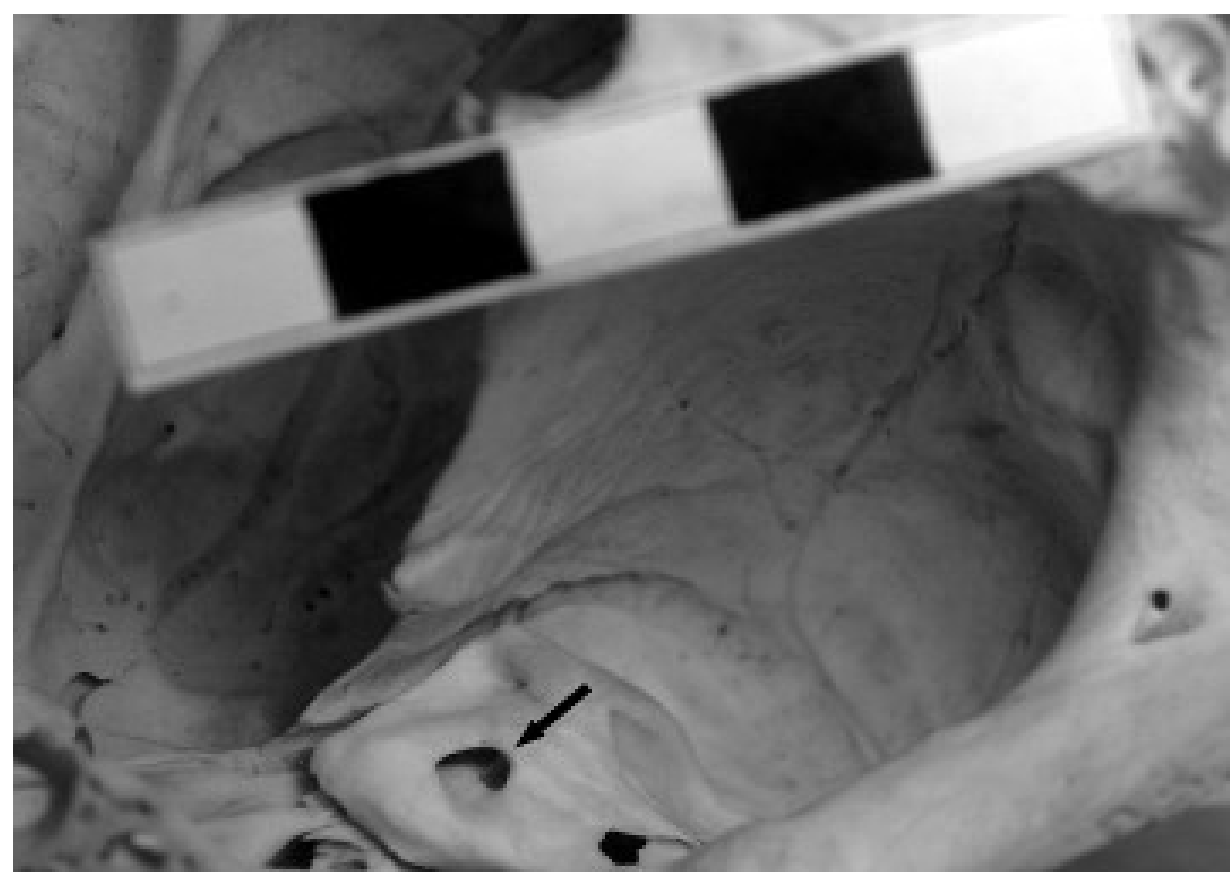

FIGURE 9: Presence of the lingual cingulum in the third upper incisor of Arctocephalus australis (MCN 2509; scale, $5 \mathrm{~cm}$ ).

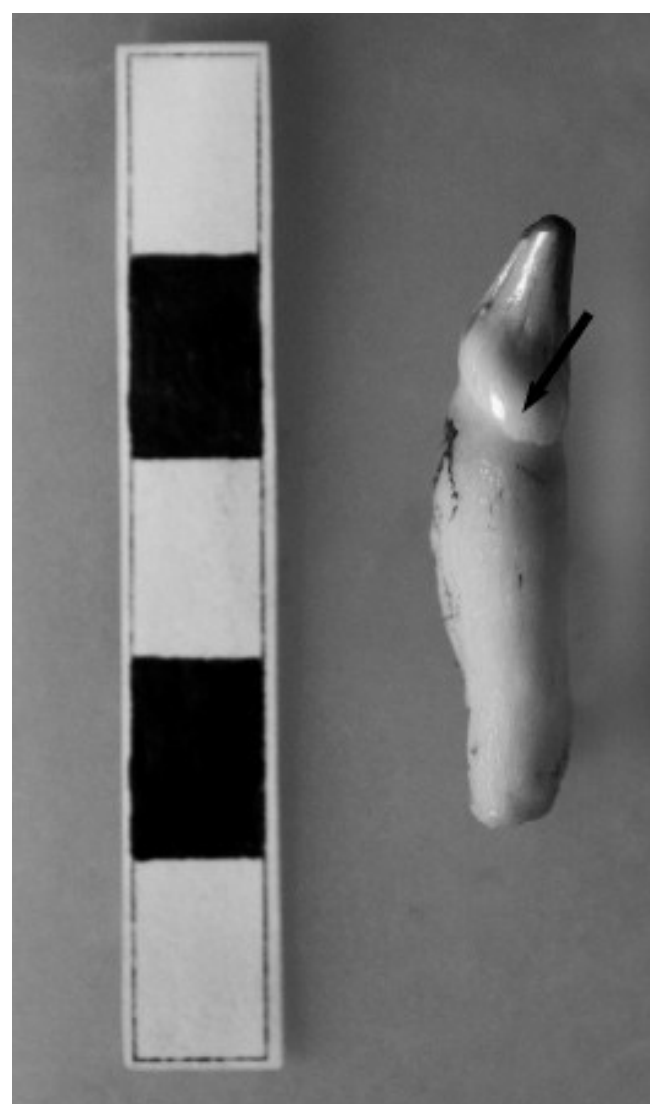

Berta and Deméré (1986) believed that the PC2/ is single-rooted in Otariidae (character 6), which was not observed in Arctocephalus australis. In this species, the tooth can be single-or double-rooted. In juvenile specimens, the lingual side shows a conspicuous sulcus that extends from the crown to the end of the root. The observed vertical sulcus in the root of these teeth, as well as the presence of an apical constriction, shows that the root is not single (Figure 10).

Berta and Wyss (1994) proposed two states of the character for the $\mathrm{PC} 3$ / roots - double or single - (character 62). The authors affirmed that in Arctocephalus and in "Otariinae" this tooth is single-rooted, which was not corroborated in the present work, where the root is double in general, with the distal portion much thicker. The sulcus on the lingual and/or vestibular sides is very clear (e.g. MCN 2602). With regard to the PC4/ roots, this is a multi-state character (4 states) according to the interpretation of the above-mentioned authors, which suggests problems in the understanding of tooth root anatomy. Repenning and Tedford (1977) considered that the PC3-4/ with a single root is a synapomorphy of all recent otariids. In the species studied here, teeth 
FIGURE 10: Apical constriction and vertical sulcus on the root of the second upper postcanine of Arctocephalus australis (MCN 2456: a, lingual view; b, apical view; scale, $5 \mathrm{~cm}$ ).

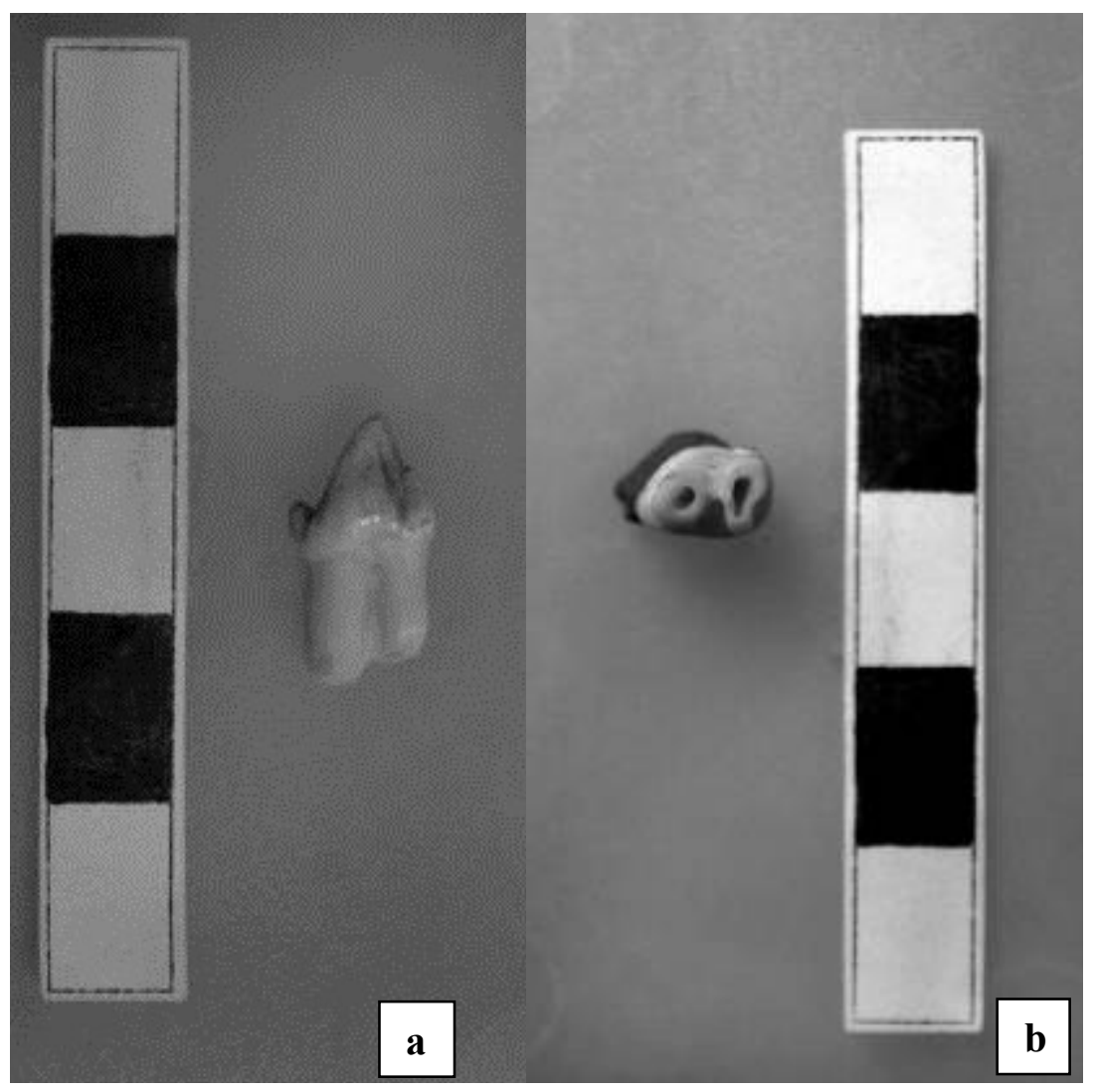

showed evidence of more than a single root. In $O$. byronia, the root can be bifid in both teeth (e.g. MCN 2624) and the sulcus of the lingual side is generally well defined, despite the fact that the sulcus on the vestibular side could be absent. In opposition, in some specimens we observed up to two sulci on the lingual side (e.g. MCN 2619). In A. australis, there are two complete roots, sometimes only partially separated. The sulcus on the lingual and vestibular sides of roots can be easily observed. Additionally, the root possesses a distal side, with a sulcus present or not (e.g. MCN 2501, 2509, 2456) (Figure 11a-b).

Berta and Wyss (1994) stated that the PC5/ would also be single-rooted, both in Arctocephalus and sea lion species. However, it was observed that this root is often bifid in $O$. byronia (the vertical sulcus is well defined, even in adult specimens (Figure 12a). Additionally in the specimen MCN 2624, two sulci on the vestibular side and one on the lingual side could be observed. In A australis, the root can be double (MCN 2699) (Figure 12b) or even triple, with considerable individual variation. The mesial root was inclined anteriorly and the distal root was very shallow and narrow, with one or two sulci.

Berta and Wyss (1994) also considered that the metaconid of the $\mathrm{PC} / 5$ is reduced or absent in sea lion species, which contradicts our results in O. byronia. In this species, the degree of development of the metaconid is variable, but it can be very conspicuous in some specimens (e.g. MCN 2624, 2701) (Figure 13a-b). 
FIGURE 11: Multiple roots in the fourth upper postcanine of Arctocephalus australis (MCN 2456: a, vestibular view; b, apical view; scale, $5 \mathrm{~cm})$.

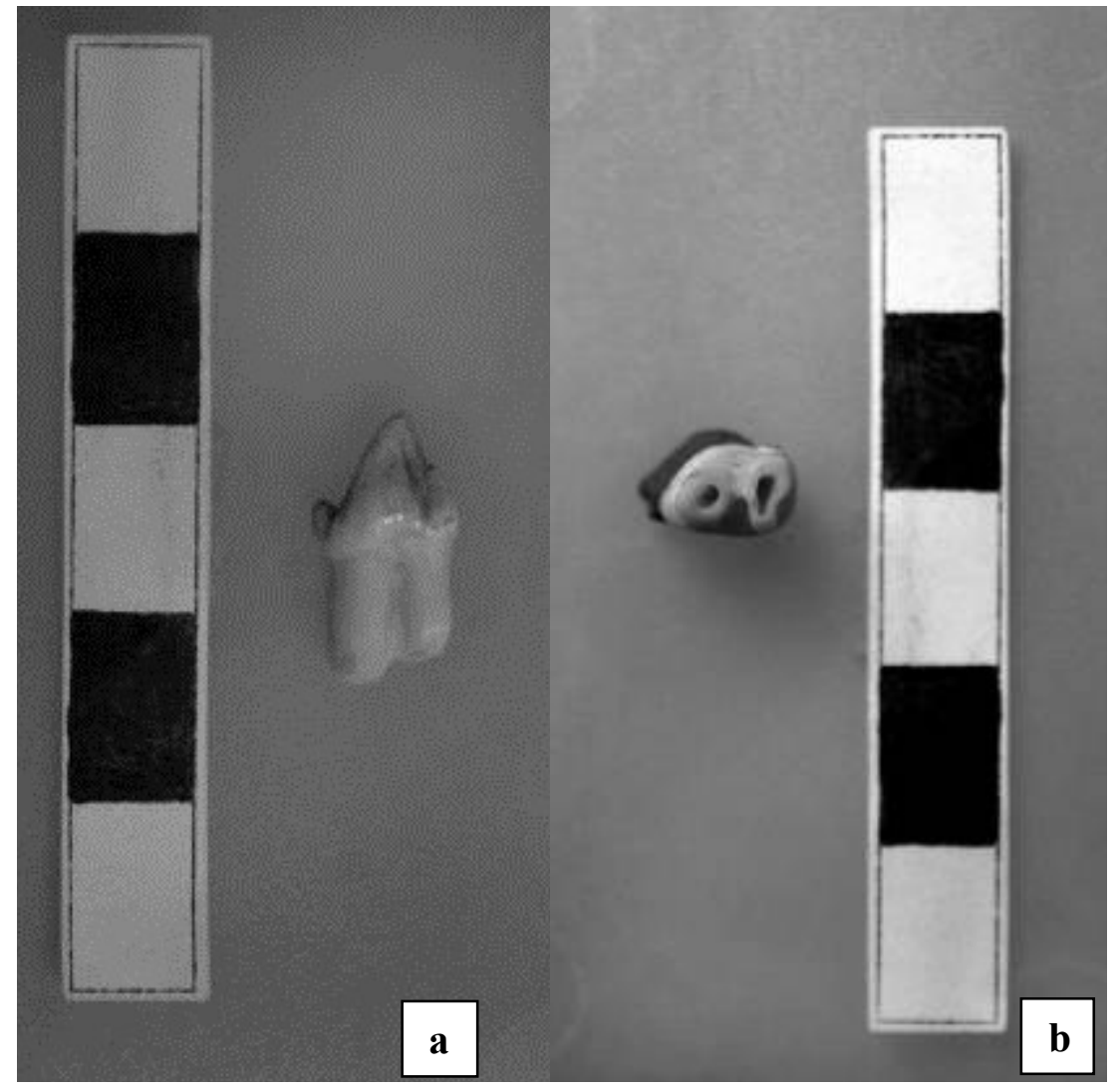

FIGURE 12: Multiple roots in the fifth upper postcanines (a, MCN 2624 Otaria byronia, vestibular view; b, MCN 2699 Arctocephalus australis, vestibular view; scale, $5 \mathrm{~cm}$ ).

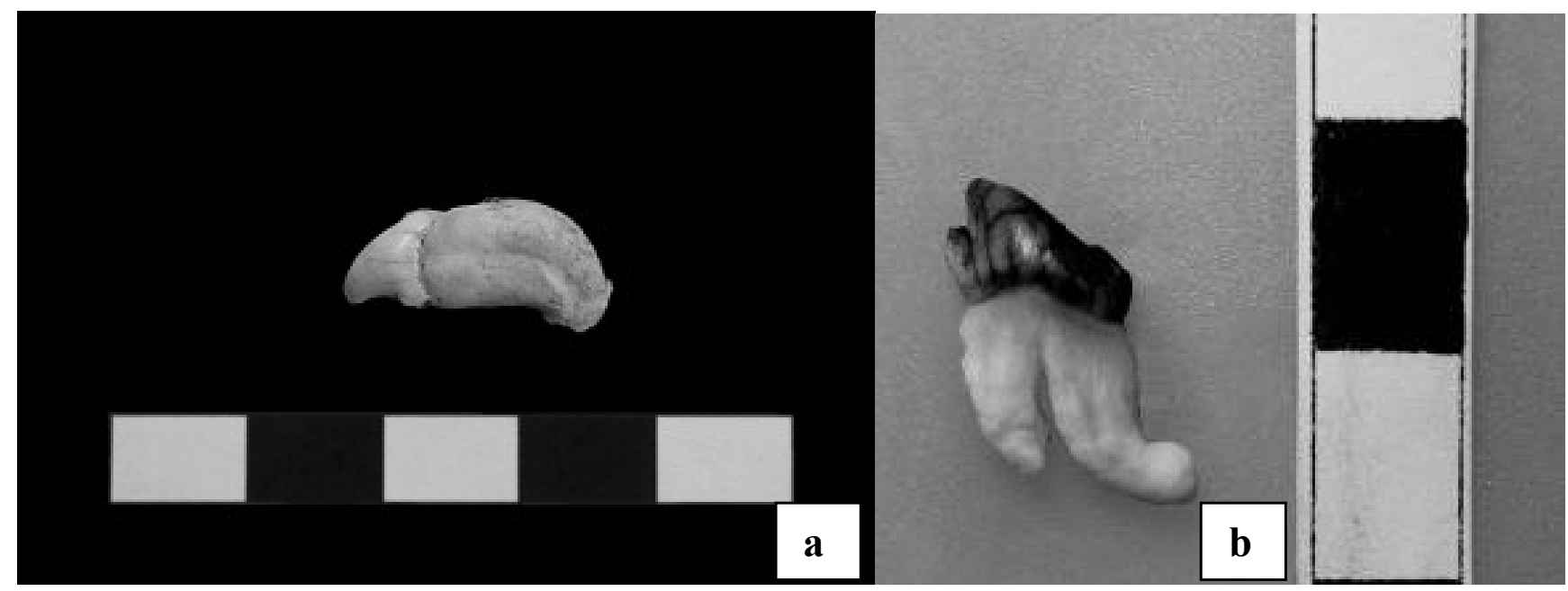


FIGURE 13: Conspicuous metaconid in the fifth lower postcanine of Otaria byronia (MCN 2701 a, vestibular view; b, lingual view; scale, $5 \mathrm{~cm})$.

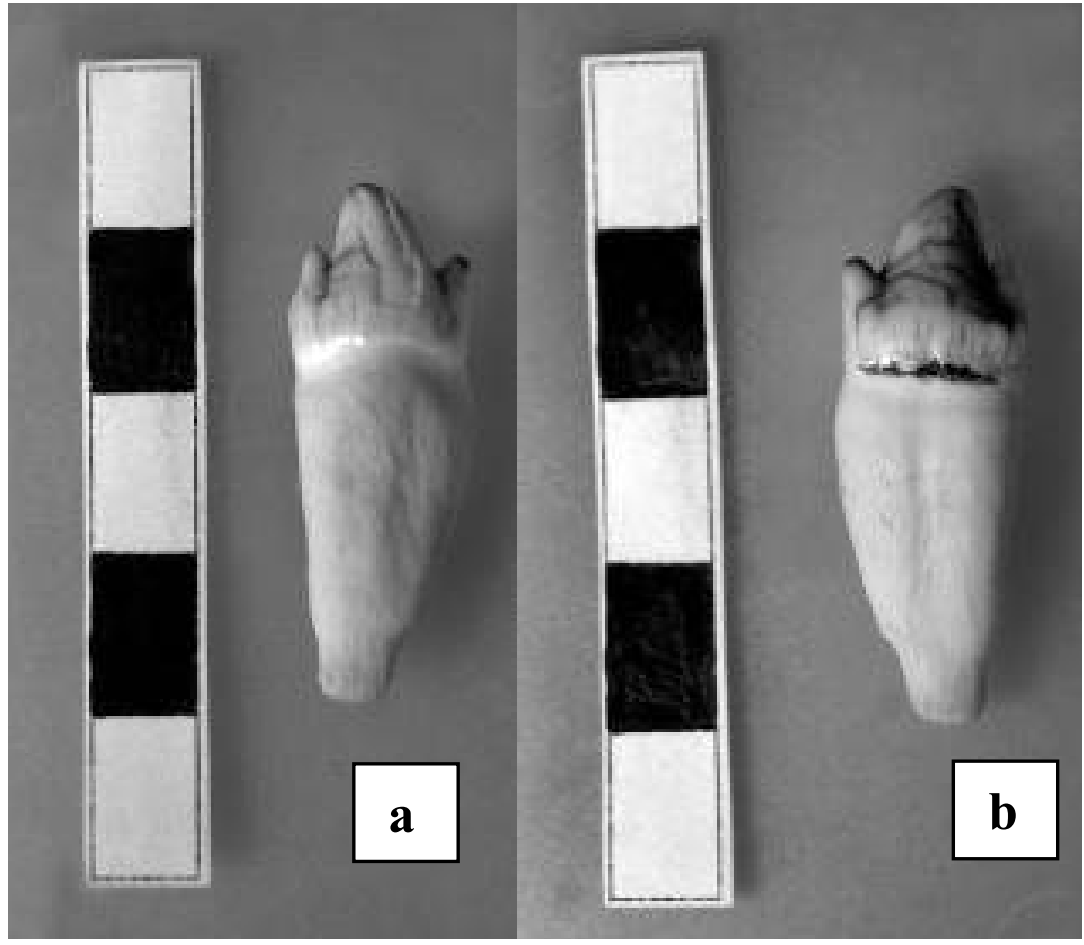

\section{Discussion}

Unlike Pinnipedia, the monophyly of Otariidae is not controversial. Nonetheless, many characters that have been attributed to the whole family in previous phylogenetic analyses vary between species. This confirms the necessity for more extensive and detailed studies of South American species, including large sample sizes, as recommended by Berta and Churchill (2012). Sanfelice and Ferigolo (2008) emphasized the high variability of skull characters in $O$. byronia and $A$. australis, refuting many character states previously used in the phylogenetic analysis of pinnipeds. In this context, these authors concluded that a comparative osteological study of all other otariids will certainly be very useful to the solution this problem and to the revision of the characters.

In relation to the jugal-squamosal contact, $O$. byronia resembles more closely Neophoca cinerea, as illustrated by King (1960). Otherwise, the shape of this suture is related to the lesser development of the post-orbital process in both species. Also considering that there is a positive allometric growth in the orbit of Arctocephalus (DREHMER; FERIGOLO, 1997), it is possible that the same also occurs for other otariids, which could be related to the type of jugal-squamosal contact.

Regarding the tympanic anatomy, its great variability was already previously mentioned in King (1960), so the relief of these bones does not seem to have a relevant taxonomic value, unless this variability is considered (e.g. DREHMER; OLIVEIRA, 2000 for Arctocephalus).

Despite a small elevation in the internal auditory meatus floor observed in some specimens of $O$. byronia (which could perhaps be interpreted as an incipient/ reduced transverse crest), it would not separate canals for the facial and auditory nerves. In fact, the absence of separate canals for nerves VII and VIII is usual in Otariidae (REPENNING; TEDFORD, 1977).

The presence of a lingual cingulum in the I3/ of Otariidae has not been previously described in the literature. With regard to the tooth roots in otariids, 
the gradual deposition of cement throughout ontogeny makes it difficult to determine the number of roots in each tooth. Mitchell (1968) noted that a fossil specimen of Eumetopias sp. cf E. jubata. would be an excellent example of a very old sea lion, given its large size and the degree of fusion between the roots. However, such "fusion" also occurs in the fur seals $A$. australis and $A$. tropicalis (DREHMER; FERIGOLO, 1997), in the most anterior postcanines. Also, according to Mitchell (1975), the development of single roots in the postcanines is a derived condition among the "Otarioidea." The majority of studies (e.g. BERTA; WYSS, 1994) refer to the root anatomy in a confusing way (especially in fossils), using few informative terms such as "bilobed roots," which in reality indicates more than a single root. Thus, we suggest that a histological study would be necessary to determine with precision the number of tooth roots in each species.

The presence of a nasolabialis fossa in some specimens of both species could be regarded as atavistic. Its occurrence in adult specimens and its morphological identity to the same structure described for the fossil genera Enaliarctos and Pteronarctos supports this claim. Some evidence of atavism in the dentition of Otaria byronia is well documented (DREHMER et al., 2004, DREHMER et al., 2009), so the nasolabialis fossa could also be subject to reversal (= taxic atavism) as observed in Pinnarctidion (BERTA; WYSS, 1994).

Finally, it is important to note that some studies have shown that dental characters of mammals (usually treated independently in phylogenetic analyses), are strongly correlated ontogenetically (KANGAS et al., 2004) or subject to atavisms (e.g. DREHMER et al., 2004). Thus, we recommend caution in the use of dental characters with regard to cusp morphology, number of teeth or number of roots.

\section{Acknowledgments}

To the Paleontology and Mastozoology Sections of the Museu de Ciências Naturais (Fundação Zoobotânica Estado do Rio Grandes do Sul). LAMAq, Universidade Federal de Santa Catarina; Museu de Zoologia, UNISINOS, for access to the scientific collections; and to Eduardo Quadros for photographs. The senior author was partially supported by a fellowship from Coordenadoria de Aperfeiçoamento Pessoal (CAPES), Conselho Nacional de Desenvolvimento Científico e Tecnológico (CNPq), Fundação de Amparo à Pesquisa do Rio Grande do Sul (FAPERGS) and Society for Marine Mammalogy (Small Grant-in-Aid). Dr. A. Leyva helped with English editing of the manuscript.

\section{References}

ANDREESCU, I.; MURARIU, D. Contributions a l'étude du crâne de quelques représentants des familles des Otariidae et Phocidae (Mammalia - Pinnipedia). Travaux du Muséum National d'Histoire Naturelle "Grigore Antipa", Paris, v. XXVII, p. 317324, 1985.

ÁRNASON, U.; GULLBERG, A.; JANKE, A.; KULLBERG, M.; LEHMAN, N.; PETROV, E. A.; VÄINÖLÄ, R. Pinniped phylogeny and a new hypothesis for their origin and dispersal. Molecular Phylogenetics and Evolution, San Diego, v. 41, p. 345-354, 2006.

BARNES, L. G. Miocene Desmatophocinae (Mammalia: Otariidae) from California. University of California Publications in Geological Sciences, Berkeley, v. 89, p. 1-68, 1972.

BARNES, L. G. Fossil enaliarctine pinnipeds (Mammalia: Otariidae) from Pyramid Hill, Kern County, California. Contributions in Science, Los Angeles, v. 318, p. 1-41, 1979.

BARNES, L. G. An Early Miocene pinniped of the genus Desmatophoca (Mammalia: Otariidae) from Washington. Contributions in Science, Los Angeles, v. 382, p. 1-20, 1987.

BARNES, L. G. A new Enaliarctine pinniped from the Astoria Formation, Oregon, and a classification of the Otariidae (Mammalia: Carnivora). Contributions in Science, Los Angeles, v. 403, p. 1-28, 1989.

BARNES, L. G. A new Miocene enaliarctine pinniped of the genus Pteronarctos (Mammalia: Otariidae) from the Astoria Formation, Oregon. Contributions in Science, Los Angeles, v. 422, p. 1-20, 1990.

BARNES, L. G. A new genus and species of Middle Miocene Enaliarctinae pinniped (Mammalia, Carnivora, Otariidae) from the Astoria Formation in coastal Oregon. Contributions in Science, Los Angeles, v. 431, p. 1-27, 1992.

BERTA, A. New Enaliarctos (Pinnipediomorpha) from the Oligocene and Miocene of Oregon and the role of "Enaliarctids" in pinniped phylogeny. Smithsonian Contributions to Paleobiology, Washington, v. 69, p. 1-33, 1991.

BERTA, A. New specimens of the Pinnipedform Pteronarctos from the Miocene of Oregon. Smithsonian Contributions to Paleobiology, Washington, v. 78, p. 1-30, 1994.

BERTA, A.; CHURCHILL, M. Pinniped taxonomy: review of currently recognized species and subspecies, and evidence used for their description. Mammal Review, London, v. 42, n. 3, p. 207234,2012 
BERTA, A.; DEMÉRÉ, T. A. Callorhinus gilmorei n. sp., (Carnivora: Otariidae) from the San Diego Formation (Blancan) and its implications for otariid phylogeny. Transactions of the San Diego Society of Natural History, San Diego, v. 21, p. 111-126, 1986.

BERTA, A.; WYSS, A. Pinniped Phylogeny. In: BERTA, A.; DEMÉRÉ, T. A. (Ed.). Contributions in marine mammal paleontology honoring Frank C. Whitmore, Jr. San Diego. Vol. 29. San Diego: Proceedings of San Diego Natural History, 1994. p. 33-56.

CRUWYS, E.; FRIDAY, A. E. Visible supernumerary teeth in pinnipeds. Polar Record, Cambridge, v. 31, n. 176, p. 45-62, 2006.

DASMAHPATRA, K. K., HOFFMAN, J. I.; AMOS, W. Pinniped phylogenetic relationships inferred using AFLP markers. Heredity, Edinburgh, v. 103, p. 168-177, 2009.

DAVIS, C. S.; DELISLE, I.; STIRLING, I.; SINIFF, D. B.; STROBECK, C. A phylogeny of the extant Phocidae inferred from complete mitochondrial DNA coding regions. Molecular Phylogenetics and Evolution, San Diego, v. 33, p. 363-377, 2004.

DEMÉRÉ, T. A.; BERTA, A. A reevaluation of Proneotherium repenningi from the Miocene Astoria Formation of Oregon and its position as a basal odobenid (Pinnipedia: Mammalia). Journal of Vertebrate Paleontology, Norman, v. 21, p. 279-310, 2001.

DEMÉRÉ, T. A.; BERTA, A. The Miocene pinniped Desmatophoca oregonensis Condon, 1906 (Mammalia: Carnivora), from the Astoria Formation, Oregon. Smithsonian Contributions to Paleobiology, Washington, v. 93, p. 113-147, 2002.

DEMÉRÉ, T. A.; BERTA, A. New skeletal material of Thalassoleon (Otariidae: Pinnipedia) from the late Miocene-early Pliocene (Hemphillian) of California. Bulletin of Florida Museum of Natural History, Gainesville, v. 45, p. 379-411, 2005.

DEMÉRÉ, T. A.; BERTA, A.; ADAM, P. J. Pinnipedimorph evolutionary biogeography. Bulletin of the American Museum of Natural History, New York, v. 279, p. 32-76, 2003.

DREHMER, C. J. Pinnipedia Illiger, 1811: uma abordagem histórica e epistemológica sobre classificação, evolução e paleontologia. Acta Geologica Leopoldensia, São Leopoldo, v. XXIII, n. 50, p. 91-105, 2000.

DREHMER, C. J.; DORNELlES, J. E. F.; LOCH, C. Variações na fórmula dentária de Otaria byronia (Blainville) (Pinnipedia, Otariidae) no Pacífico: registro de um novo tipo de anomalia. Neotropical Biology and Conservation, São Leopoldo, v. 4, n. 1, p. 28-35, 2009.

DREHMER, C. J.; FABIAN; M. E.; MENEGHETI, J. O. Dental anomalies in the Atlantic population of South American sea lion, Otaria byronia (Pinnipedia, Otariidae): evolutionary implications and ecological approach. LAJAM, Rio de Janeiro, v. 3, n. 1, p. 7-18, 2004.

DREHMER, C. D.; FERIGOLO, J. Descrição do sincrânio de Arctocephalus australis (Pinnipedia, Otariidae). Iheringia Série Zoologia, Porto Alegre, v. 81, p. 63-74, 1996a.

DREHMER, C. D.; FERIGOLO, J. Anomalias e patologias dentárias em Arctocephalus G. Saint-Hilaire; Cuvier (Pinnipedia, Otariidae) da costa do Rio Grande do Sul, Brasil. Revista Brasileira de Zoologia, Curitiba, v. 13, p. 857-865, 1996b.

DREHMER, C. D.; FERIGOLO, J. Osteologia craniana comparada entre Arctocephalus australis e Arctocephalus tropicalis
(Pinnipedia, Otariidae). Iheringia Série Zoologia, Porto Alegre, v. 83, p. 137-149, 1997.

DREHMER, C. J.; OLIVEIRA, L. R. Syncranial osteology of Arctocephalus gazella (Pinnipedia, Otariidae) from Rio Grande do Sul, Brazil. Iheringia Série Zoologia, Porto Alegre, v. 88, p. 5159, 2000.

DREHMER, C. J.; RIBEIRO, A. M. A left temporal bone of an Otariidae (Mammalia, Pinnipedia) from the late Pleistocene of Rio Grande do Sul State, Brazil. Revista da Universidade de Guarulhos Geociências, Guarulhos, v. 8, n. 6, p. 39-44, 1998.

ENGLISH, A. W. M. Structural correlates of forelimb function in fur seals and sea lions. Journal of Morphology, Philadelphia, v. 151, p. 325-352, 1977.

FLYNN J. J.; FINARELLI, J. A.; ZEHR, S.; HSU, J.; NEDBAL, M. A. Molecular phylogeny of the Carnivora (Mammalia): assessing the impact of increased sampling on resolving enigmatic relationships. Systematic Biology, Washington, v. 54, p. 317-337, 2005.

GARDNER, A. L.; ROBBINS, C. B. Case 3058. Arctocephalus F. Cuvier, 1826 and Callorhinus Gray, 1859 (Mammalia, Pinnipedia); proposed conservation by the designation of Phoca pusilla Schreber, 1775 as the type species of Arctocephalus; and Otaria Pe'ron, 1816 and Eumetopias Gill, 1866; proposed conservation by the designation of Phoca leonina Molina 1782 as the type species of Otaria. Bulletin of Zoological Nomenclature, London, v. 56, p. 136-141, 1999.

HERSHKOWITZ, P. Basic crown patterns and cusp homologies of mammalian teeth. In: DAHLBERG, A. A. (Ed.). Dental morphology and evolution. Chicago: University of Chicago, 1971. p. 95-150.

HIGDON, J. W.; BININDA-EMONDS, O. R. P.; BECK, R. M. D.; FERGUSON, S. H. Phylogeny and divergence of the pinnipeds (Carnivora: Mammalia) assessed using a multigene dataset. BMC Evolutionary Biology, London, v. 7, p. 216, 2007.

HOWELL, A. B. Contribution to the comparative anatomy of the eared and earless seals (genera Zalophus and Phoca). Proceedings of the United States National Museum, Washington, v. 73, n. 15, p. 1-142, 1929.

ICZN - INTERNATIONAL COMMISSION ON ZOOLOGICAL NOMENCLATURE. Opinion 1962. Arctocephalus F. Cuvier, 1926 and Callorhinus Gray, 1959 (Mammalia, Pinnipedia): conserved by the designation of Phoca pusilla Schreber, 1775 as the type species of Arctocephalus; and Otaria Pe'ron, 1816 and Eumetopias Gill,1866: conserved by the designation of Phoca leonina Molina, 1782 as the type species of Otaria. Bulletin of Zoological Nomenclature, London, v. 57, p. 193-195, 2000.

INTERNATIONAL COMMITTEE ON VETERINARY GROSS ANATOMICAL NOMENCLATURE. Nomina Anatomica Veterinaria. 4 ed. Zurich: World Association of Veterinary Anatomists, 1994. 190 p.

KANGAS, A. T.; EVANS, A. R.; THESLEFF; I.; JERNVALL, J. Nonindependence of mammalian dental characters. Nature, London, v. 432, p. 211-214, 2004.

KASTELEIN, R. A.; GERRITS, N. M. The anatomy of the walrus head (Odobenus rosmarus). Part 1: the Skull. Aquatic Mammals, London, v. 16, p. 101-19, 1990. 
KING, J. E. Sea-lions of the Genera Neophoca and Phocartos. Mammalia, Paris, v. 24, p. 445-456, 1960.

KING, J. E. Seals of the World. 2 ed. Brisbane: University of Queensland Press, 1983.240 p.

KLAAUW, J. VAN DER. The auditory bulla in some fossil mammals. Bulletin of the American Museum of Natural History, New York, v. 62, p. 1-352, 1931.

LOCH, C.; SIMÕES-LOPES, P. C.; DREHMER, C. J. Numerical anomalies in the dentition of southern fur seals and sea lions. Zoologia, Curitiba, v. 27, p. 477-482, 2010.

MEAD, J. G.; FORDYCE, R. E. The therian skull: a lexicon with emphasis on the odontocetes. Smithsonian Contributions to Zoology, Washington, v. 627, p. 1-248, 2009.

MILlER, M. E.; CHRISTENSEN, G. C.; EVANS, H. E. Anatomy of the dog. Philadelphia and London: Saunders, 1964. 941 p.

MITCHELL, E. D. The Mio-Pliocene Pinniped Imagotaria. Journal Fisheries Research Board of Canada, Toronto, v. 25, p. 1843-1968, 1968.

MITCHELL, E. D. Parallelism and convergence in the evolution of Otariidae and Phocidae. Rapports et Procès-verbaux des Réunions du Conseil International pour Exploration de la Mer, Copenhague, v. 169, p. 12-26, 1975.

MITCHELL, E. D; TEDFORD, R. H. The Enaliarctinae. A new group of extinct aquatic Carnivora and a consideration of the origin of the Otariidae. Bulletin of the American Museum of Natural History, New York, v. 151, p. 201-284, 1973.

MIYAZAKI, N. Teeth. In: PERRIN, W. F.; WÜRSIG, B.; THEWISSEN, J. G. M. (Ed.). Encyclopedia of Marine Mammals. San Diego: Academic Press, 2002. p. 1127-1232.

MIZUNO, A. W.; OHTAISHI, N. Cranial features of the spotted seal, Phoca largha, in the Nemuro Strait, considering age effects. Journal of Veterinary Medical Science, Tokyo, v. 64, n. 2, p. 137 44, 2002.

NOJIMA, T. A morphological consideration of the relationships of pinnipeds to other carnivorans based on the bony tentorium and bony falx. Marine Mammal Science, Lawrence, v. 6, p. 54-74, 1990.

REPENNING, C. A.; PETERSON, R. S.; HUBBS, C. L. Contributions to the systematics of the southern fur seals, with particular reference to the Juan Fernandez and Guadalupe species. Antarctic Research Series, Washington, v. 18, p. 1-34, 1971.
REPENNING, C. A.; TEDFORD, R. H. Otariod Seals of Neogene. Washington: U.S. Geological Survey Professional Paper, 1977. 93 p.

ROBINETTE, H. R.; STAINS, H. J. Comparative study of the calcanea of the Pinnipedia. Journal of Mammalogy, Baltimore, v. 51, n. 3, p. 527-541, 1970.

RODRIGUEZ, D.; BASTIDA, R. The southern sea lion: Otaria byronia or Otaria flavescens? Marine Mammal Science, Lawrence, v. 9, p. 372-381, 1993.

SANFELICE, D.; FERIGOLO, J. Estudo comparativo entre os sincrânios de Otária byronia e Arctocephalus australis (Pinnipedia, Otariidae). Iheringia Série Zoologia, Porto Alegre, v. 98, p. 5-16, 2008.

SIVERTSEN, E. A survey of the eared seals (family Otariidae) with remarks on the Antarctic seals collected by $M / K$ "Norvegia" in 1928-1929. Oslo: Det Norske Videnskaps-Akademii, 1954. 76 p. TEDFORD, R. H. Relationship of pinnipeds to other carnivores (Mammalia). Systematic Zoology, Washington, v. 25, p. 363-374, 1976.

UHEN, M. D. Evolution of Marine Mammals: Back to the sea after 300 million years. The Anatomical Record, Hoboken, v. 290, p. 514-522, 2007.

WOZENCRAFT, W. C. Carnivora. In: WILSON, D. E.; REEDER, D. M. (Ed.). Mammal species of the world: a taxonomic and geographic reference. 3 ed. Baltimore: Johns Hopkins University, 2005. p. 532-628

WYSS, A. R. The walrus auditory region and the monophyly of the pinnipeds. American Museum Novitates, New York, v. 2871, p. 1-31, 1987.

WYSS, A. R. On retrogression in the evolution of the Phocidae and phylogenetic affinities of the monk seals. American Museum Novitates, New York, v. 2924, p. 1-38, 1988a.

WYSS, A. R. Evidence from flipper structure for a single origin of pinnipeds. Nature, London, 334, v. 6181, p. 427-428, 1988 b.

WYSS, A. R. Flipper and pinniped phylogeny: Has the problem of the convergence been overrated? Marine Mammals Science, Lawrence, v. 54, p. 343-360, 1989. 